\title{
Hydrocracking of Cerbera manghas Oil with Co-Ni/HZSM-5 as Double Promoted Catalyst
}

\author{
Lenny Marlinda, Muhammad Al-Muttaqii, Ignatius Gunardi, Achmad Roesyadi, \\ Danawati Hari Prajitno* \\ Chemical Reaction Engineering Laboratory, Department of Chemical Engineering, \\ Sepuluh Nopember Institute of Technology, Sukolilo, Surabaya, 60111, Indonesia
}

Received: 20th May 2016; Revised: 30th January 2017; Accepted: 10 ${ }^{\text {th }}$ February 2017

\section{Abstract}

The effect of various reaction temperature on the hydrocracking of Cerbera manghas oil to produce a paraffin-rich mixture of hydrocarbons with Co-Ni/HZSM-5 as doubled promoted catalyst were studied. The Co-Ni/HZSM-5 catalyst with various metal loading and metal ratio was prepared by incipient wetness impregnation. The catalysts were characterized by XRD, AAS, and $\mathrm{N}_{2}$ adsorption-desorption. Surface area, pore diameter, and pore volume of catalysts decreased with the increasing of metals loading. The hydrocracking process was conducted under initial hydrogen pressure in a batch reactor equipped with a mechanical stirrer. The reaction was carried out at a temperature of $300-375{ }^{\circ} \mathrm{C}$ for $2 \mathrm{~h}$. Depending on the experimental condition, the reaction pressure changed between 10 bar and 15 bar. Several parameters were used to evaluate biofuel produced, including oxygen removal, hydrocarbon composition and gasoline/kerosene/diesel yields. Biofuel was analyzed by Fourier Transform Infrared Spectroscopic (FTIR) and gas chromatography-mass spectrometry (GC-MS). The composition of hydrocarbon compounds in liquid products was similar to the compounds in the gasoil sold in unit of Pertamina Gas Stations, namely pentadecane, hexadecane, heptadecane, octadecane, and nonadecane with different amounts for each biofuel produced at different reaction temperatures. However, isoparaffin compounds were not formed at all operating conditions. Pentadecane $\left(n-\mathrm{C}_{15}\right)$ and heptadecane (n$\mathrm{C}_{17}$ ) were the most abundant composition in gasoil when Co-Ni/HZSM-5 catalyst was used. Cerbera Manghas oil can be recommended as the source of non-edible vegetable oil to produce gasoil as an environmentally friendly transportation fuel. Copyright (C) 2017 BCREC Group. All rights reserved

Keywords: Biofuel; Cerbera manghas oil; Co-Ni/HZSM-5 catalyst; Hydrocracking

How to Cite: Marlinda, L., Al-Muttaqii, M., Gunardi, I., Roesyadi, A., Prajitno, D.H. (2017). Hydrocracking of Cerbera manghas Oil with Co-Ni/HZSM-5 as Double Promoted Catalyst. Bulletin of Chemical Reaction Engineering \& Catalysis, 12 (2): 167-184 (doi:10.9767/bcrec.12.2.496.167-184)

Permalink/DOI: http://dx.doi.org/10.9767/bcrec.12.2.496.167-184

\section{Introduction}

The decline in petroleum reserves impact energy crisis. In addition, the use of fossil fuels will continually increase the accumulation of green-house gases in the atmosphere resulting in the earth's temperature increase and global

* Corresponding Author.

E-mail: dana@chem-eng.its.ac.id

Telp.: +62-31-5937968, Fax.: +62-31-5968153 climate change. This negative impacts motivate researchers to develop biofuel as an alternative renewable energy source for the future [1,2]. In fact, The European Union introduced directives 2003/30/EC, 2009/28/EC and 2014/94/EU to increase biofuel as transportation fuel [3]. In Presidential Regulation of Indonesia No. 5/2006, one of the national energy policy stated renewable energy of $17 \%$ in mix targets of the national primary energy 2025 and biofuel contri- 
bution is about $5 \%$ of renewable energy. Biofeed, such as vegetable oil, lignocellulosic biomass, algae, sewage sludge, can be feedstock to produce biofuel [4]. Non-edible vegetable oil as biofeed can be the best choice to solve the issue of competition between the use of vegetable oil as the source of food and that of the fuel [1].

Some examples of non-edible oilseed plant are Jatropha curcas L, Hevea brasiliensis (Rubber seed), Calophyllum inophyllum L. (Polanga), Cerbera manghas (Sea mango), Pongamia pinnata L. (Karanja), Aleutites fordii (Tung), Ricinus communis (Castor), and Reutalis trisperma (Blanco) Airy Shaw (sunan candlenut), etc. [1,4]. These plants can help to reduce $\mathrm{CO}_{2}$ emissions of 10 tons/hectare/year. They can grow in former mining region with low nutrient levels and rainfall. They do not compete with food sources because of containing toxic substances. The toxic component, Cerberin, is founded in Cerbera manghas oil. Therefore, this plant is grouped in nonedible vegetable oil. This tree can reach a height of 6-15 m which is part of the ecosystem of mangrove forests [1]. However, this vegetable oil can not be used directly as biofuel because they still contains high oxygen atoms, high viscosity, high freezing point, low heating value, and thermal instability $[5,6]$.

Biofuel can be obtained from transesterification and hydrocracking of biofeed. Biodiesel (fatty acid methyl esters) produced from vegetable oils by transesterification with methanol still have the structure of unsaturated fatty acids, lower energy density, poor oxidation stability and cold flow properties, because of the presence of oxygen atoms in the ester. Biofuel for transportation fuel must have a cloud point and cetane number that depends on the composition of the paraffin compounds $[1,2]$. Hydrocracking may be the preferred conversion route of vegetable oil into biofuel using hydrogen gas to selectively remove oxygen atoms as water and carbon dioxide [7]. Hydrocracking reaction of the triglycerides can consist of two main reactions routes in the process of transforming triglycerides into liquid hydrocarbon fuel, namely hydrodecarbonylation / decarboxylation (HDC) and hydrodeoxygenation (HDO), as shown in Figure 1 [2,8-11]. The reaction route may lead to the formation of hydrocarbons such as n-paraffins, isoparaffins, cycloparaffins, aromatics, and olefins [2,8,9]. Therefore, the control of the dehydrogenation reaction, isomerization, cyclization, and aromatization will be very important during hydrocracking process takes place [2]. Organic liquid product, mixture of hydrocarbons in the range of gasoline, kerosene and gasoil can be produced by the cracking/hydrocracking on nonedible vegetable oil.

The reaction temperature and types of catalysts have significant effects on the composition and quality of the liquid product [12]. Typical catalysts for catalytic cracking or hydrocracking of triglycerides can be categorized into several types: (1) molybdenum-based sulfide/non-sulfide catalysts, such as NiMoS, $\mathrm{CoMoS}, \mathrm{CoMo} / \gamma-\mathrm{Al}_{2} \mathrm{O}_{3}$, NiMo/ZSM-5-alumina, and NiMo/SAPO-11 [2,6,7,13-16], (2) Ni/Zn catalyst supported on HZSM-5 [14,17], (3) noble metals, including $\mathrm{Pd} / \mathrm{Pt}$ catalyst supported on HZSM-5 [18]. Organic liquid product obtained can be divided into groups of gasoline, kerosene and gasoil. Nickel with a high hydrogenation ability is very effective as the reduction promoter on supported Co catalysts, such as $\mathrm{Co} / \mathrm{HZSM}-5$, $\mathrm{Co} / \mathrm{SiO}_{2}$, dan $\mathrm{Co} / \mathrm{Al}_{2} \mathrm{O}_{3}$ [19].

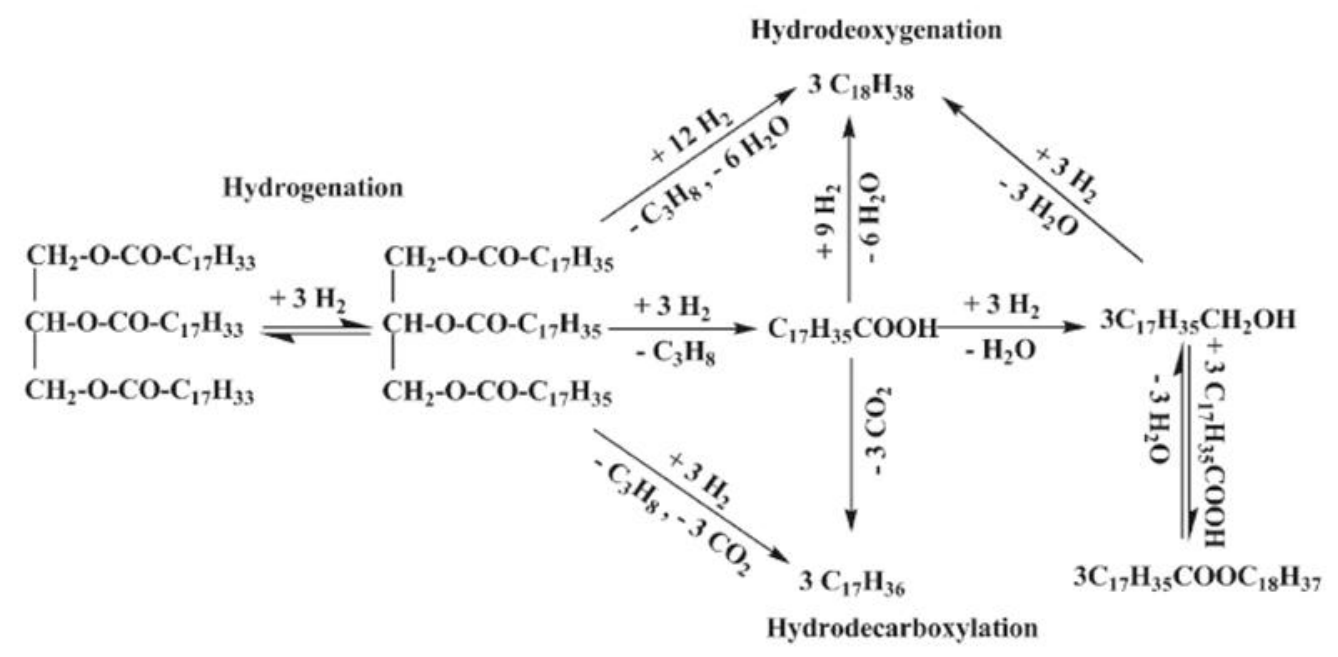

Figure 1. Triglyceride reaction scheme for conversion to hydrocarbons $[7,11]$ 
Based on this, it is very interesting for impregnating double promoter of $\mathrm{Co}$ and $\mathrm{Ni}$ metals into HZSM-5 [8,20].

In this study, Co-Ni/HZSM-5 catalyst was well prepared in order to obtain the properties of the catalyst used to increase the degree of hydrocracking on Cerbera manghas oil. The influence of the reaction temperature in forming the hydrocarbon compounds, such as paraffin (normal and iso-), cycloparaffin, aromatic, and olefin, in biofuel were also studied.

\section{Materials and Methods}

Cerbera manghas oil is extracted from seeds of fruits, as shown in Figure 2(c) and (b). This plants can be found as greening plant in Surabaya, Indonesia. From two kilograms of seeds were pressed with screw press mechine, oil content is about one liter. Before the seeds were pressed, they have been dried in the sun for \pm 7 days. Oil content is 50 wt.\%. This same result was reported by Atabani et al. [1] i.e. the seed oil content of $54 \mathrm{wt} \%$ and kernel oil of $6.4 \mathrm{wt} \%$. Cerbera manghas oil was analyzed using gas chromatography-mass spectrometry (GC-MS) with chromatogram as shown in Figure 8(a). Analysis results in Table 1 indicates that the main abundant component in Cerbera manghas oil contains oleic acid of $76.21 \%$. The main abundant component Cerbera manghas oil used in this research has a high content of mono-unsaturated fatty acids. Atabani et al. [1] also stated that oleic acid of $48.1 \%$ is mainly fatty acid of Cerbera manghas oil.

The $\mathrm{NH}_{4}$-ZSM-5 zeolite were taken from Zeolyst International (CBV 8014, a surface area of $400 \mathrm{~m}^{2} / \mathrm{g}, \mathrm{Na}_{2} \mathrm{O}$ content less than 0.05 wt.\%), while $\mathrm{Ni}\left(\mathrm{NO}_{3}\right)_{2} .6 \mathrm{H}_{2} \mathrm{O}$, and $\mathrm{Co}\left(\mathrm{NO}_{3}\right)_{2} .6 \mathrm{H}_{2} \mathrm{O}$ was purchased from Merck with $\geq 98 \%$ purity. The Co-Ni/HZSM-5 catalyst was prepared with procedure as reported by Marlinda et al. [38]. The sample HZSM-5 was modified by designed concentration of $\mathrm{Ni}\left(\mathrm{NO}_{3}\right)_{2} .6 \mathrm{H}_{2} \mathrm{O}$ and $\mathrm{Co}\left(\mathrm{NO}_{3}\right)_{2} .6 \mathrm{H}_{2} \mathrm{O}$ aqueous solution with incipient wetness impregnation method [21-25]. In the sequential impregnation method, Ni first was loaded by the impregnation into HZSM-5 and the catalyst was kept overnight in a desiccator and dried at $120{ }^{\circ} \mathrm{C}$ for $12 \mathrm{~h}$. Then, Co was loaded on Ni/HZSM-5 catalyst by the impregnation and the catalyst was kept overnight in a desiccator and dried at $120^{\circ} \mathrm{C}$ for $12 \mathrm{~h}$. The catalyst was calcined at $400{ }^{\circ} \mathrm{C}$ in air for $2 \mathrm{~h}$ and reduced in flowing $\mathrm{H}_{2}$ at $450{ }^{\circ} \mathrm{C}$ for 3 , as reported in previous study $[2,26]$.

By atomic absorption spectrometry, the metals content was 6.54 wt.\% of $\mathrm{Ni}$ and 1.05

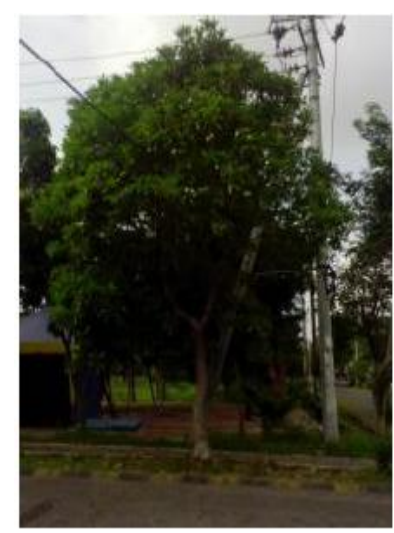

(a)

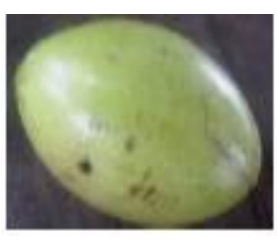

(b)

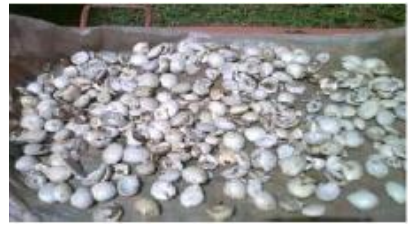

(c)

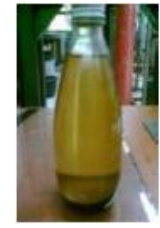

(d)

Figure 2. Cerbera manghas (a) plant, (b) fruit, (c) seeds, dan (d) oil

Table 1. Fatty acid composition of Cerbera manghas oil tested by GC-MS

\begin{tabular}{cccc}
\hline Fatty acid & Chemical name & Molecular formula & Composition, \% \\
\hline Palmitic acid, C16:0 & Hexadecanoic acid & $\mathrm{C}_{15} \mathrm{H}_{31} \mathrm{COOH}$ & 1.66 \\
Pentadecylic acid; C15:1 & 14-Pentadecenoic acid & $\mathrm{C}_{14} \mathrm{H}_{27} \mathrm{COOH}$ & 16.78 \\
Oleic acid; C18:1 & 9-Octadecenoic acid & $\mathrm{C}_{17} \mathrm{H}_{33} \mathrm{COOH}$ & 76.21 \\
Linoleic acid; C18:2 & 9,17- Octadecadienal & $\mathrm{C}_{17} \mathrm{H}_{31} \mathrm{COOH}$ & 4.30 \\
\hline
\end{tabular}


wt.\% of Co of the total catalyst weight. The sample of the catalyst is denoted as Co-Ni(10\%;1:3)/HZSM-5 catalyst. Other prepared catalysts with different metal loading and me-tals ratio were shown in Table 2 .

XRD diffraction patterns of the catalyst were measured by a PANalytical X'Pert MPD diffractometer with a $\mathrm{Cu}-\mathrm{K} \alpha$ as source of X-ray operating at $40 \mathrm{kV}$ and $30 \mathrm{~mA}$. Samples were scaned in the range $2 \theta$ of $5-90^{\circ}$ with a step size of 0.017 and scan step time of $10.15 \mathrm{~s}$. The existence of the crystalline phase of $\mathrm{NiO}, \mathrm{Ni}, \mathrm{Co}_{3} \mathrm{O}_{4}$, $\mathrm{CoO}$ and $\mathrm{Co}$ particles was confirmed from the diffraction patterns recorded on $2 \theta=30-80^{\circ}$. SEM intrument (model:EVO MA10) was used to study the surface morphology of HZSM-5 equipped with energy-dispersive X-ray analysis spectroscopy (EDX) to determine the $\mathrm{Si} / \mathrm{Al}$ composition.

The total surface area and pore volume of the catalyst were derived from $\mathrm{N}_{2}$ adsorptiondesorption isotherms recorded with a Quanta- chrome NovaWin Version 11.03 instrument calculated by the Brunauer-Emmett-Teller (BET). Micropore size distribution was derived from the Horvath-Kawazoe (H-K) method. Before the measurement of $\mathrm{N}_{2}$ adsorptiondesorption isotherms at a temperature of $77 \mathrm{~K}$, the sample was outgassed at $120^{\circ} \mathrm{C}$ for $8 \mathrm{~h}$.

Figure 3 shows the equipment used to make biofuel from Cerbera manghas oil by hydrocracking process. The hydrocracking process was conducted under hydrogen initial pressure in batch reactor equipped with a mechanical stirrer. The Cerbera Manghas oil of $200 \mathrm{ml}$ was placed into the reactor, which contained the catalysts of $1 \mathrm{~g}$. Then, reactor was purged with $\mathrm{N}_{2}$ to remove air dissolved in oil or in the reactor for 30 minutes, as reported in previous study [12]. The catalyst was activated under flowing $\mathrm{H}_{2}$ for $1 \mathrm{~h}$ to reaction temperature in reactor. In previous study, Martinez-Grimaldo et al. [27] activated hydrocracking catalyst at $350{ }^{\circ} \mathrm{C}$ for $1 \mathrm{~h}$. The reaction was carried out at

Table 2. The properties of catalyst

\begin{tabular}{lcccccc}
\hline \multirow{2}{*}{ Catalyst } & \multirow{2}{*}{$\begin{array}{c}\text { BET surface area, } \\
\mathrm{m}^{2 / g}\end{array}$} & $\begin{array}{c}\text { Total pore } \\
\text { volume }, \mathrm{cm}^{3} / \mathrm{g}\end{array}$ & $\begin{array}{c}\text { Average pore } \\
\text { diameter, nm }\end{array}$ & \multicolumn{2}{c}{$\begin{array}{c}\text { Actual metal } \\
\text { content, wt.\% }\end{array}$} \\
\cline { 6 - 8 } Co-Ni(5\%;1:1)/HZSM-5 & 376.716 & 0.2852 & 1.514 & Co & ni \\
Co-Ni(5\%;1:3)/HZSM-5 & 373.070 & 0.2764 & 1.481 & n.d & n.d \\
Co-Ni(10\%;1:1)/HZSM-5 & 340.611 & 0.2473 & 1.452 & n.d & n.d \\
Co-Ni(10\%;1:3)/HZSM-5 & 341.824 & 0.2463 & 1.441 & 1.05 & 6.54 \\
\hline
\end{tabular}

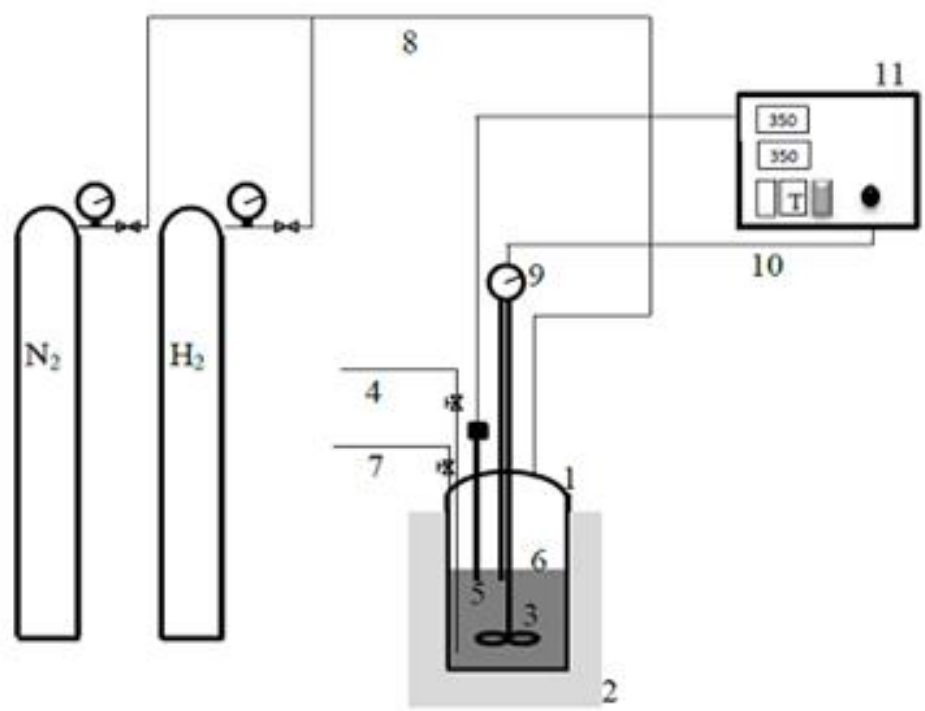

Figure 3. Hydrocracking Process Equipment, consist of (1) reactor, (2) heater, (3) stirrer, (4) liquid sampling tube, (5) thermocouple, (6) cerbera manghas oil, (7) tube gas outlet, (8) tube reactor of $\mathrm{N}_{2} / \mathrm{H}_{2}$, (9) reactor pressure indicator, (10) stirrer controler, (11) the control panel of heater reactor 
a temperature of $300,325,350$, and $375^{\circ} \mathrm{C}$ for 2 h. Depending on the experimental condition, the reaction pressure changed between 10 bar and 15 bar.

Liquid products were analyzed by gas cromatography-mass spectrometry with standard GC: Agilent HP 6890 models 19091S-433, HP$5 \mathrm{MS}$ capillary column $30 \mathrm{~m} \times 250 \mu \mathrm{m} \times 0.25$ $\mu \mathrm{m}$. It was held at nominal initial pressure 13.3 psi and the temperature for the oven was at $150{ }^{\circ} \mathrm{C}$ for $2 \mathrm{~min}$, then it increased to $240{ }^{\circ} \mathrm{C}$ at a rate of $10{ }^{\circ} \mathrm{C} / \mathrm{min}$ for $11 \mathrm{~min}$. The calculations of biofuel yield grouped into gasoline, kerosene and gasoil were based on GC-MS without using external and internal standards. The peak area normalization method based on peak area per percentages of the identified components was used to quantify GC-MS results. All hydrocarbon components were identified using the Wiley275 and NIST02 mass spectral library of data. The hydrocarbon components with a

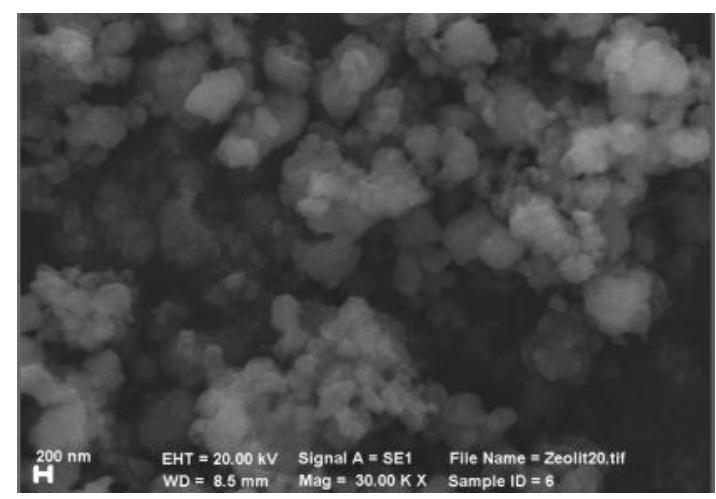

(a) probability match equal to or higher than $80 \%$ were considered. Hydrocarbons (i.e. paraffin, aromatic, cycloparaffin, and olefin) contained in biofuel were defined as gasoline-like hydrocarbon (C5-C9), kerosene-like hydrocarbon (C10-C13), and gasoil-like hydrocarbon (C14$\mathrm{C} 22$ ), as reported by Barron et al. [28]. Definition of biofuel yield was as shown in Equation (1).

Yield $(\%)=\frac{\text { biofuel }(\text { area\% }) \text { xliquid productmass }(g)}{\text { oilmass }(g)}$

Fourier transformed infrared (FTIR) spectroscopy analyses were performed on the liquid product to determine the functional groups present in Cerbera Mangas oil and biofuel to understand the oxygen removal. The instrument used was the thermo scientific Nicolet iS10 FTIR spectrometer with resolution of operating in the range of $4000-400 \mathrm{~cm}^{-1}$.

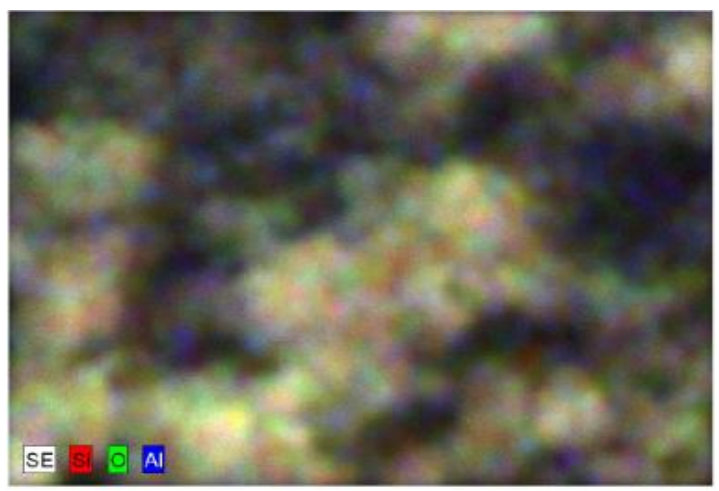

(b)

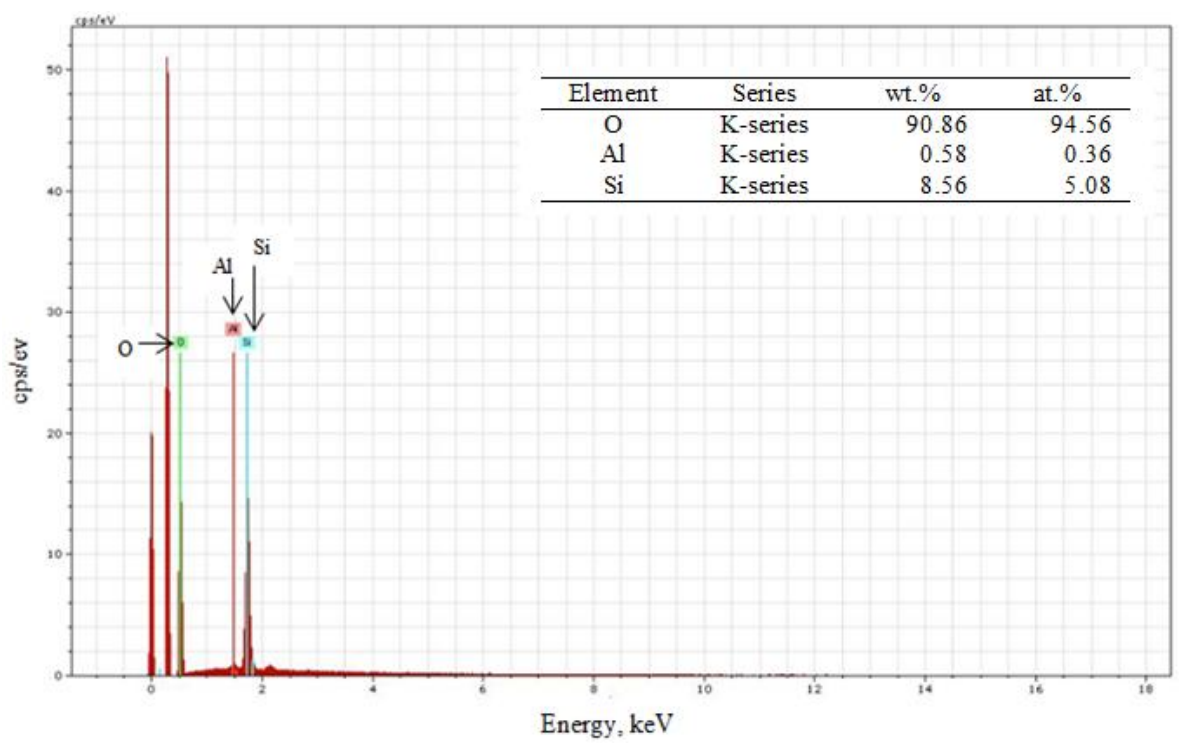

(c)

Figure 4. SEM image (a) and the corresponding EDX patterns (b,c) of HZSM-5 obtained from the calcined $\mathrm{NH}_{4}$-ZSM-5 zeolite 


\section{Results and Discussion}

\subsection{Characterization of catalysts}

Figure 4(a) shows that the morphology of HZSM- 5 is visible in the form of a uniform cluster. Figure 4(b) and (c) show the distribution and concentration of $\mathrm{Si}$ and $\mathrm{Al}$ metals in HZSM- 5 based on the results of the measurements of SEM-EDX, i.e. Si/Al ratio of 14 . The X-ray diffraction pattern of HZSM-5 are presented in Figure 5(a) and full characterization of HZSM-5 used in this study was as reported by previous study [38]. The characteristics peaks indicate that HZSM-5 have a framework type MFI. Figure 5(b-e) show the X-ray diffraction pattern of catalyst used for hydrocracking process of Cerbera manghas oil. XRD data analysis of catalyst shows the full diffractogram recorded in the range $2 \theta$ of $5-90^{\circ}$ to see the diffraction peak of $\mathrm{NiO}, \mathrm{CoO}, \mathrm{Co}_{3} \mathrm{O}_{4}, \mathrm{Ni}$ and Co in catalyst.

In Figure 5 (b-e), XRD patterns of CoNi/HZSM-5 catalysts show that the XRD patterns were similar to the characteristic structure of the commercial HZSM-5 in Figure 5(a). Metals loading do not change the crystal structure of HZSM-5 but reduce the intensity of each diffraction peak, same as reported in a previous study [23-25,29,30,38], because metals on the surface can decrease the scattering of X-rays. Figure 5(b) and (d) show that a weak diffraction peaks intensity of $\mathrm{Co}_{3} \mathrm{O}_{4}$ were observed at the $2 \theta$ of $19.2^{\circ}$ and $45^{\circ}$ according to ICDD : 00-042-1467 and $\mathrm{NiO}$ was observed at $2 \theta=37.4^{\circ}$ according to ICDD: 00-044-1159. However, the main diffraction peak of $\mathrm{CoO}$ (ICDD:00-042-1300) was observed at $2 \theta$ of $34.3^{\circ}$, as shown in Figure 5(b). These phases are not identified on the catalysts, as shown in Figure 5(c) and (e). There is a possibility that $\mathrm{NiO}$ is very small and not detectable, even for the catalyst with the highest nickel content. The other author also stated that nickel impregnated on Co/HZSM- 5 can reduce the cobalt oxide into metallic phase of cobalt [19]. It can be said that the nickel and cobalt can be dispersed well on all catalysts. Referring ICDD data with reference code: 00-004-0850, the main peaks of nickel were observed at the $2 \theta$ of $44.5^{\circ}$ and $52^{\circ}$. Meanwhile, the main peak of cobalt was observed at $44.3^{\circ}$ according to ICDD: 00-015-0806. The presence of $\mathrm{CoO}$ indicated that the reduction process of catalyst required a amount of hydrogen and a reduction time sufficiently to obtain the metallic phase of cobalt. On the other hand, the results of AAS measurement proved the presence of cobalt and nickel in $\mathrm{Co}-\mathrm{Ni}(10 \% ; 1: 3) / \mathrm{HZSM}-5$ catalyst, as shown in Table 2.

Table 2 shows the properties of Co-Ni/HZSM- 5 catalyst. It shows that the BET surface area, pore diameter, and total pore volume of catalysts decrease with the increasing of metals loading. Metals ratio of cobalt and nickel did not significantly influence on the properties of catalyst in the same metals loading. The micropores size of all catalysts loaded with various ratio of metals almost unchanged and centered at about $0.48 \mathrm{~nm}$ calculated by the Horvath-Kawazoe (H-K) method, as shown in Figure 6. The previous authors stated that, the addition of a number of metals cause microporous surface area and micropore volume reduced. Both of these metals block microporous area and clog mesoporous area so that the total surface area less than before impregnated [23-25,29,30]. Nickel particles did play an important role for the high activity of Co-Ni/HZSM-5 catalyst. Nickel had high hydrogenation ability and a good potential to break carbon-carbon bonds [19,24].

\subsection{Catalytic activity}

\subsubsection{FTIR analysis}

The FTIR spectra of Cerbera manghas oil may be compared to that of biofuel obtained at $375{ }^{\circ} \mathrm{C}$ for 120 min using $\mathrm{Co}-\mathrm{Ni}(10 \% ; 1: 1) /$ HZSM-5 catalyst to evaluate hydrocracking reaction such as deoxygenation and decarboxylation through the disappearance of the absorption peaks corresponding to functional groups of oxygenated compounds as shown in Figure 7. The increase in the absorption peaks corresponding to hydrocarbon $\mathrm{C}-\mathrm{C}$ bonds was also observed.

Esters of $1743 \mathrm{~cm}^{-1}$ and $1159 \mathrm{~cm}^{-1}$, saturated and unsaturated alkanes of 2852, 2921, and $3006 \mathrm{~cm}^{-1}$ are absorption bands typical of several functional groups in vegetable oils presented in Figure 7(a). The absorption band in the region from 3400 to $3500 \mathrm{~cm}^{-1}$ for $\mathrm{O}-\mathrm{H}$ bonds of alcohols or carboxylic acids is not observed in FTIR spectra. It shows that the initial Cerbera manghas oil had a very low free fatty acid. This result was in agreement with previous reports [31].

Figure 7(b) shows that the ester bands at $1743 \mathrm{~cm}^{-1}$, i.e. carbonyl groups of $-\mathrm{C}=\mathrm{O}$ stretch and $1159 \mathrm{~cm}^{-1}$, i.e. acid or ester groups of -C-O stretch are not observed in FTIR spectra of biofuel obtained at $375{ }^{\circ} \mathrm{C}$ and 120 min with the $\mathrm{Co}-\mathrm{Ni}(10 \% ; 1: 1) / \mathrm{HZSM}-5$ catalyst. It indicated that the oxygen removal through cracking and hydrogenation of the ester bonds occurred. On the other hand, the absorption 


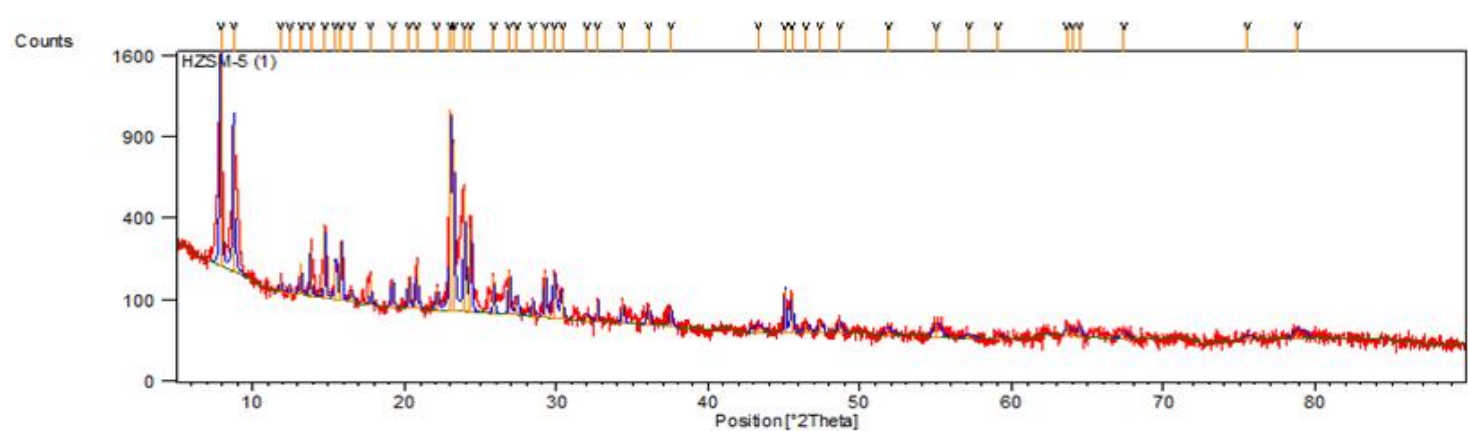

(a)

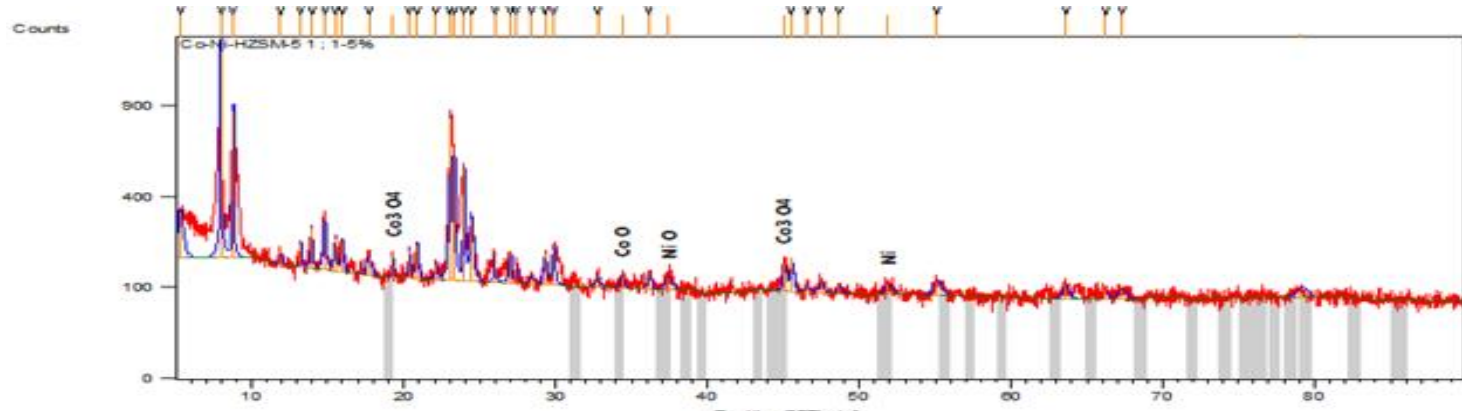

(b)

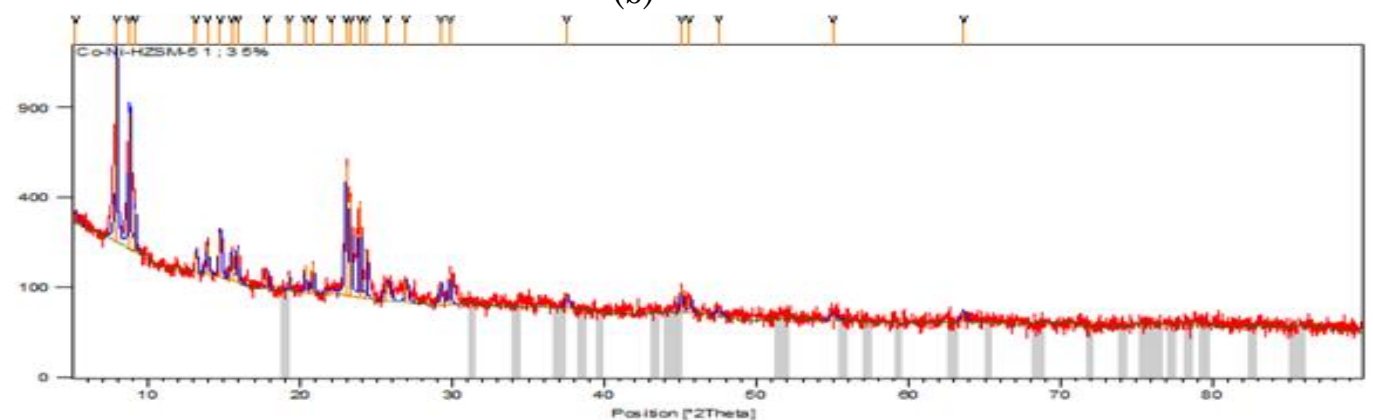

(c)
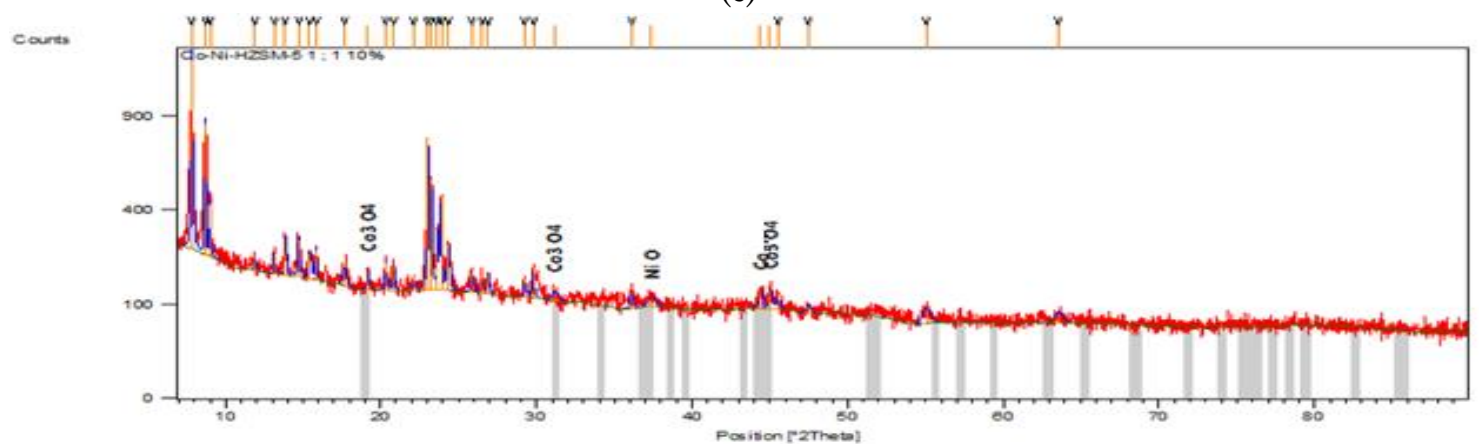

(d)

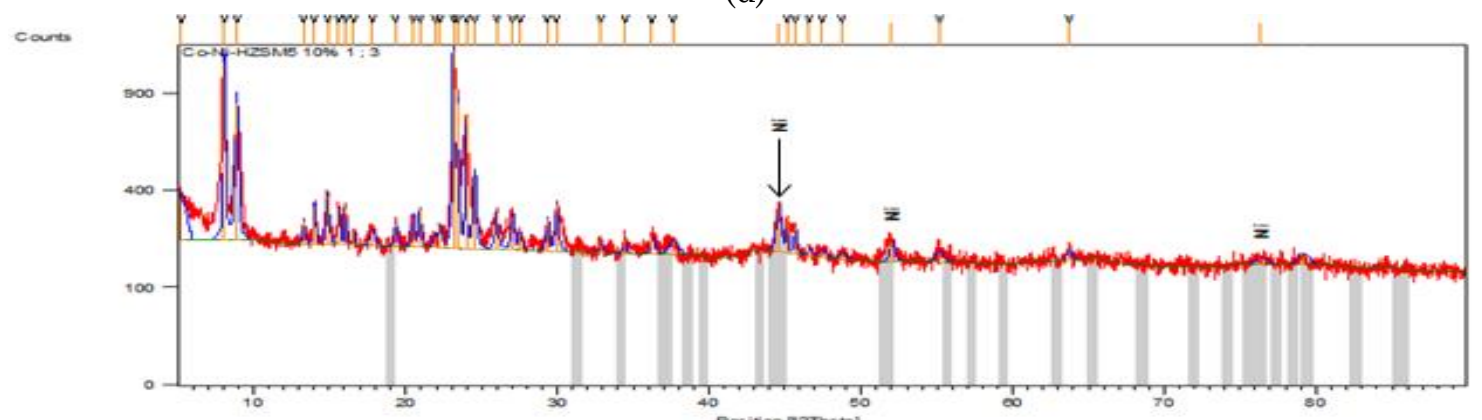

(e)

Figure 5. XRD patterns of the catalyst: (a) HZSM-5 [38], (b) Co-Ni(5\%;1:1)/HZSM-5, (c) CoNi(5\%;1:3)/HZSM-5, (d) Co-Ni(10\%;1:1)/HZSM-5, (e) Co-Ni(10\%;1:3)/HZSM-5 


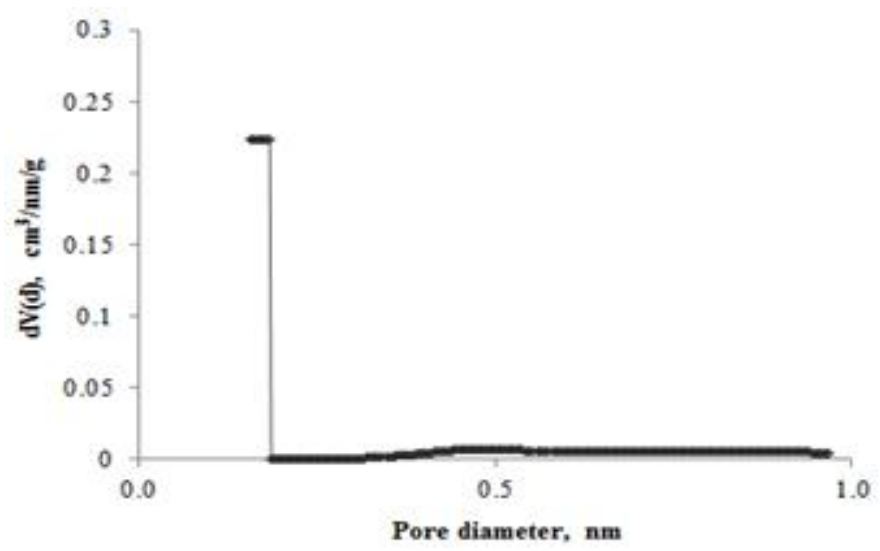

Figure 6. The H-K micropore size distribution of the Co-Ni(5\%;1:1)/HZSM-5 catalyst

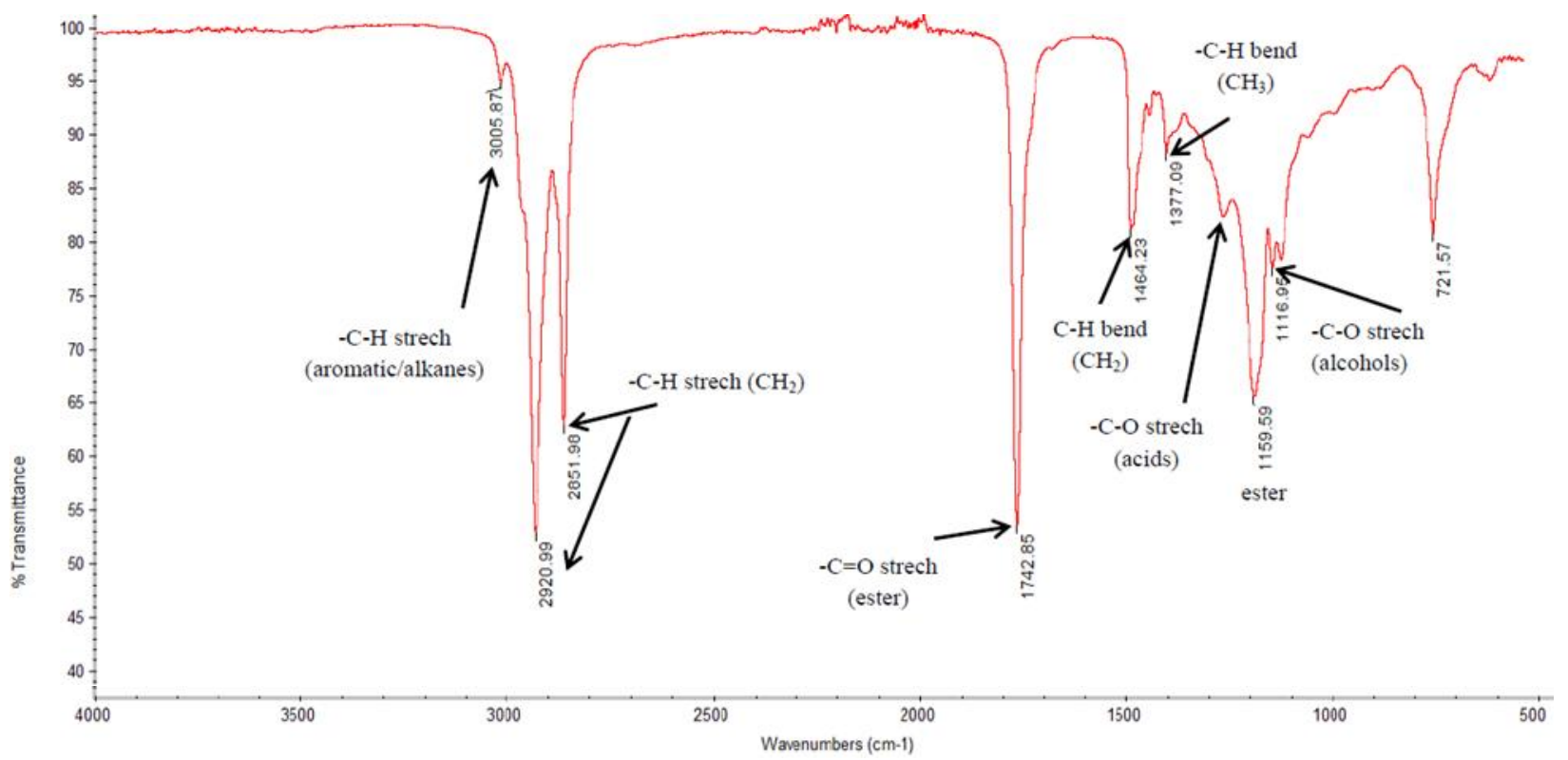

(a)

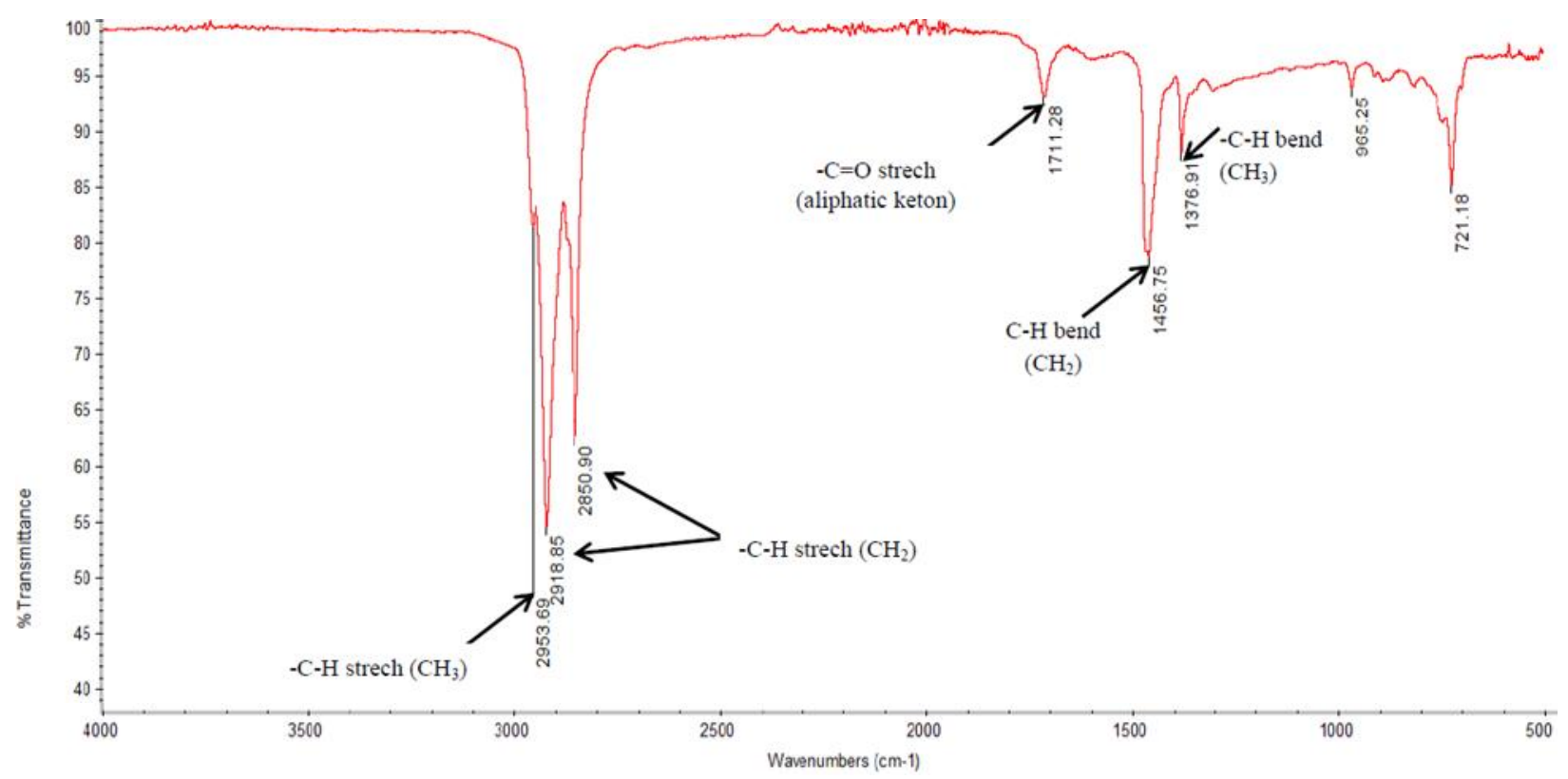

(b)

Figure 7. FTIR spectra of (a) Cerbera manghas oil, (b) liquid product obtained at $375{ }^{\circ} \mathrm{C}$ for $120 \mathrm{~min}$ using $\mathrm{Co}-\mathrm{Ni}(10 \% ; 1: 1) / \mathrm{HZSM}-5$ catalyst 
bands are visible in the region between 2851 $\mathrm{cm}^{-1}$ and $2954 \mathrm{~cm}^{-1}$ for alkyl groups of the $-\mathrm{C}-\mathrm{H}$ bonds. It can be said that the hydrocarbon content increased in biofuel when compared to the Cerbera manghas oil. However, the absorption band at $1711 \mathrm{~cm}^{-1}$ show that biofuel still contained oxygenated compounds and/or a small amount of $-\mathrm{COOH}$ group, which was confirmed with carboxylic acids of 2.83 area\% detected by the GC-MS analysis. It's the same as observed in the Cerbera manghas oil. The $\mathrm{O}-\mathrm{H}$ absorption band in the region from 3400 to $3500 \mathrm{~cm}^{-1}$ is not also observed in biofuel. According to Pinto et al. [31], it indicated that deoxygenation and/or decarboxylation reactions converted the free fatty acids from the decomposition of triglycerides to produce hydrocarbons.

\subsubsection{GC-MS analysis}

GC-MS spectra of Cerbera manghas oil and biofuel produced in the various reaction temperature are shown in Figure 8. Figure 8(a) shows that the compounds with retention time of 10-18 min in the Cerbera manghas oil disappear after hydrocracking reaction [38]. Figure 8(b) and (c) shows chromatograms of Cerbera manghas oil after hydrocracking reaction. It shows that the amounts of different hydrocarbon compounds with retention time of 0-12 min in biofuel increase after reaction. Triglycerides of Cerbera manghas oil were converted into short chain molecules by cracking, cyclization, aromatization, isomerization reactions [32]. The reaction sequence may include interconnected reactions of triglyceride molecules and intermediates, such as hydrogenolysis forming fatty acids, and propane, deoxygenation of carboxylic groups in fatty acids, cyclization, dehydrogenation of cyclic ring to aromatic ring, hydrocracking of alkil chains, and isomerization of alkil chains [33].

\subsubsection{Effect of temperature on hydrocarbon composition}

Figure 9 shows that biofuel has a hydrocarbon composition with a different amount for each hydrocracking reaction temperature. Based on GC-MS analysis, n-paraffin, olefin, cyloparaffin, aromatic, other oxygenated compounds, including carboxylic acids, esters, ketones and alcohols are produced by hydrocracking of Cerbera manghas oil as reported in previous study $[28,34,35]$. However, isoparaffin compounds are not formed at all operating conditions. The rise of temperature to $375{ }^{\circ} \mathrm{C}$, formation of $n$-paraffin increase. The presence of oxygenated compounds showed the tendency to increase in the number of n-paraffin with the increasing reaction temperature of over $350{ }^{\circ} \mathrm{C}$. Cycloparaffin also increased with the increasing reaction temperature. Cycloparaffin was possible to increase in the presence of olefins. Sotelo-Boyás et al. [34] stated that isoparaffin formation was influenced by acid strength of active site of HZSM-5. On the other hand, the rise of reaction temperature was necessary considered because of the addition the reaction temperature can also lead to increase formation of coke. Hao et al. [23] and SoteloBoyás et al. [34] stated that thermal cracking of olefins through the route decarbonylation and ability of Brönsted acid of active site on HZSM-5 catalyst provided proton $\left(\mathrm{H}^{+}\right)$can affect the rate of cycloparaffin and aromatic formation.

Figure 9(a) shows that the most abundant hydrocarbon of aromatics and cycloparaffins are 6.16 area\% and 13.88 area\%, respectively at a temperature of $375{ }^{\circ} \mathrm{C}$ with $\mathrm{Co}-\mathrm{Ni}(5 \% ; 1: 1) /$ HZSM-5 catalyst. The branched chain cyclohexane was found in biofuel produced. The dehydrogenation of cyclohexane produced aromatic compounds found in compounds, i.e. methylnaphtalene, 2-methylnapthalene, 2,3dimethyl-naphtalene, nonylbenzene, pentylbenzene and octylbenzene. However, the aromatic compounds has not been formed at reaction temperatures ranging from $300-350{ }^{\circ} \mathrm{C}$ as shown in Figure 9(a), (b), and (d). Long chain alkyl aromatics were posibble to produce olefins through cracking reactions. Table 3 represents the abundant compounds in biofuel which can be divided into each type of hydrocarbons at $375{ }^{\circ} \mathrm{C}$ with $\mathrm{Co}-\mathrm{Ni}(5 \% ; 1: 1) / \mathrm{HZSM}-5$ catalyst. Aromatic compounds were also found in the biofuel produced at a temperature of 375 ${ }^{\circ} \mathrm{C}$ with $\quad \mathrm{Co}-\mathrm{Ni}(10 \% ; 1: 1) / \mathrm{HZSM}-5$ catalyst, i.e. pentylbenzene, methylnaphthalene, nheptylbenzene, octylbenzene, and nonylbenzene. Pinto et al. [31] stated that the increasing reaction temperature and gas product could reduce the partial pressure of hydrogen during hydrogenation. At this condition, cracking reactions and dehydrogenation reactions may occur. Both of these reactions could promote cyclization reaction leading to aromatic formation. Figure 9(a) and (c) clearly show this phenomenon. The reaction temperature further rises lead to increase aromatic compounds formed as well as increased cycloparaffin.

Figure 9(b) shows that the most abundant hydrocarbon of the n-paraffins is 68.98 area\% of $375{ }^{\circ} \mathrm{C}$ with the $\mathrm{Co}-\mathrm{Ni}(5 \% ; 1: 3) / \mathrm{HZSM}-5$ catalyst. This result was in the same range as reported by Kim et al. [2]. At temperature of 

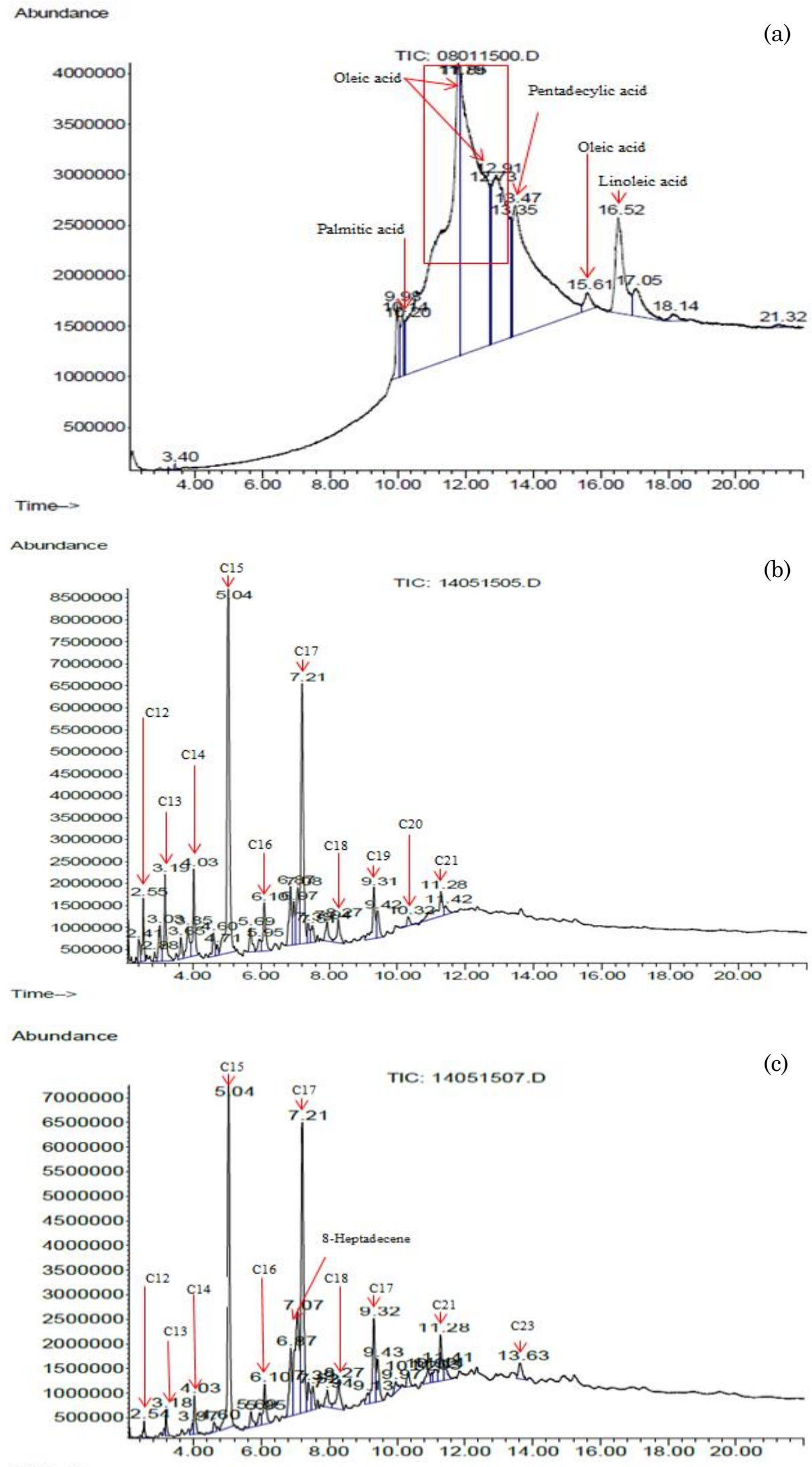

Figure 8. GC-MS spectra of (a) Cerbera manghas Oil [38], (b) liquid product produced at $375{ }^{\circ} \mathrm{C}$, using Co-Ni(5\%;1:3)/HZSM-5 catalyst, (c) liquid product produced at $375{ }^{\circ} \mathrm{C}$, using Co-Ni(10\%;1:3)/HZSM-5 catalyst, under 15 bar in the batch reactor. Saturated chain hydrocarbons (n-paraffins) have the number of carbon atom from $\mathrm{C} 12$ to $\mathrm{C} 23$ 
$300{ }^{\circ} \mathrm{C}$, oxygenated compounds of 10.88 area $\%$ were found in significant amounts as shown in Figure 9(c). Figure 9(a), (b) and (d) also show that oxygenated compounds decrease with the increasing temperature. This reaction was more favorable at high temperature. The n-paraffins, i.e. pentadecane (n-C15) and heptadecane (n-C17), were produced in the reaction temperature of $300-375{ }^{\circ} \mathrm{C}$ through decarboxylation and decarbonylation with various composition of the $\mathrm{Ni}$ catalyst. This result was similar to Kim et al. [2] stated that higher rates of decarboxylation and decarbonylation with the $\mathrm{Ni}$ catalyst indicated significant $\mathrm{C}-\mathrm{C}$ bond scission took place. The $\mathrm{C}-\mathrm{C}$ bond scission leads to the oxygen removal so that produces $\mathrm{CO}_{2}$ or $\mathrm{CO}$ as a byproduct, whereas $\mathrm{C}-\mathrm{O}$ bond scission produces $\mathrm{H}_{2} \mathrm{O}$. Catalysts containing transition metal as an active material, such as $\mathrm{Ni}, \mathrm{Pd}$, and $\mathrm{Pt}$, exhibited higher catalytic activity on $\mathrm{C}-\mathrm{C}$ bond scission [2]. Vichaphund et al. [35] stated that HZSM-5 increased the cover-ting oxygenated compounds to aromatics and aliphatics.

When the Co-Ni(10\%;1:3)/HZSM-5 catalyst was used at a temperature of $375{ }^{\circ} \mathrm{C}$, the carboxylic acid and oxygenated compounds were completely converted to hydrocarbon compound as shown in Figure 9(d). Carboxylic acids formed at this temperature were completely converted into n-paraffin of 63.93 of area\%, olefin of 22.6 area $\%$, cycloparaffin of 7.8 area $\%$ and aromatics of 1.3 area\%. Sotelo-Boyás et al. [34] stated that $\mathrm{NiO}$ and $\mathrm{Co}_{3} \mathrm{O}_{4}$ phase undetectable on HZSM5 had an important role in catalytic cracking of $\mathrm{C}-\mathrm{C}$ bond, $\mathrm{C}=\mathrm{O}$ double bond and $\mathrm{R}-\mathrm{O}$ bond in carboxylic acids. Liu et al. [36] also reported that the level of cracking also depended on the acid strength and amount of the catalysts. Double promoter of cobalt and nickel could change the strength of the acidity of HZSM-5 as support. Table 4 represents the

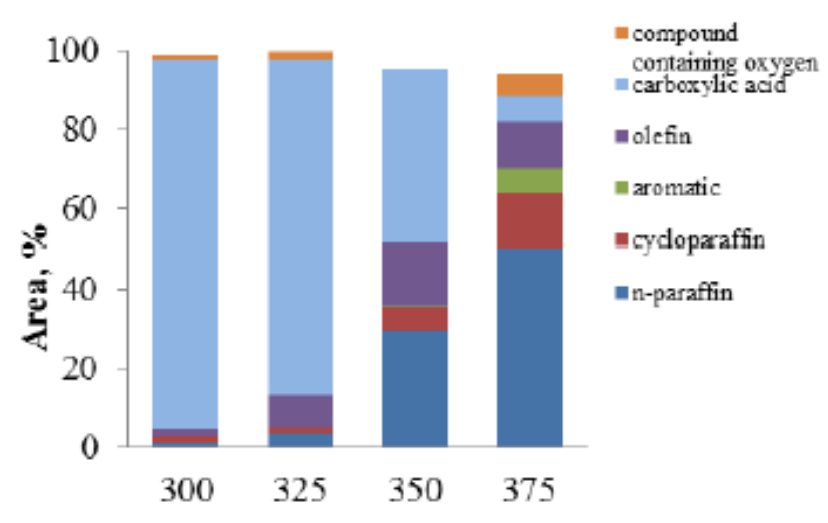

Reaction Temperature, ${ }^{\circ} \mathrm{C}$

(a)

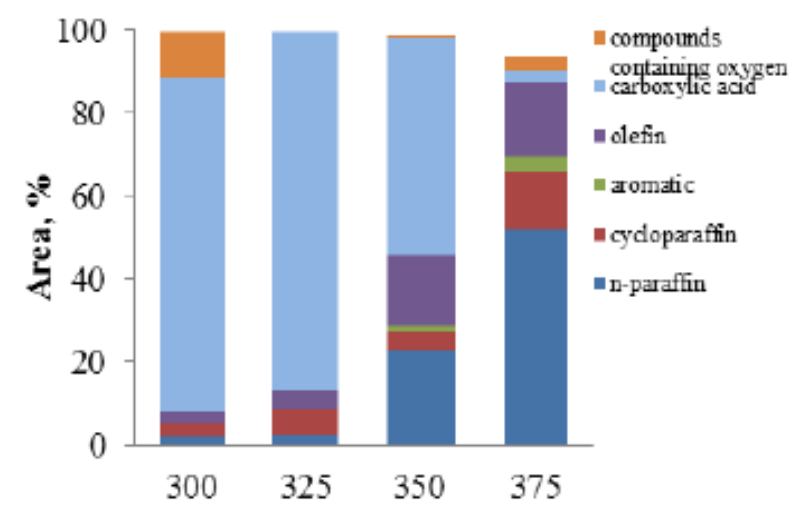

Reaction Temperature, ${ }^{\circ} \mathrm{C}$

(c)

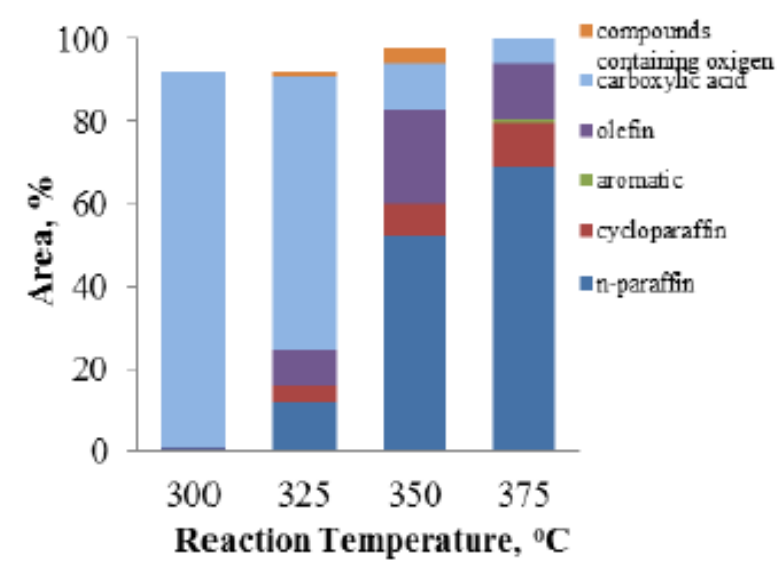

(b)

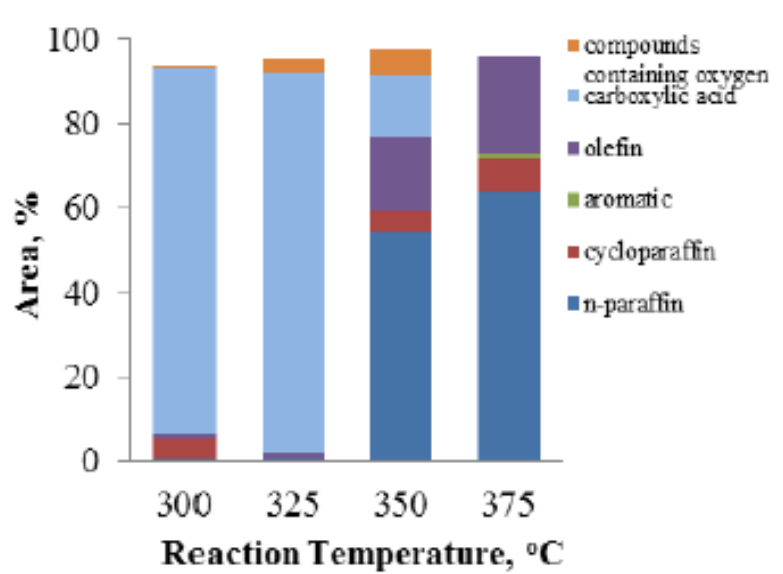

(d)

Figure 9. Effect of reaction temperature on the hydrocarbon composition using (a) CoNi(5\%;1:1)/HZSM-5 catalyst, (b) Co-Ni(5\%;1:3)/HZSM-5 catalyst, (c) Co-Ni(10\%;1:1)/HZSM-5 catalyst, (d) $\mathrm{Co}-\mathrm{Ni}(10 \% ; 1: 3) / \mathrm{HZSM}-5$ catalyst, under 15 bar in the batch reactor 
Table 3. Several abundant compounds* in each group for liquid product produced at temperature of $375{ }^{\circ} \mathrm{C}$, under 15 bar in the batch reactor with $\mathrm{Co}-\mathrm{Ni}(5 \% ; 1: 1) / \mathrm{HZSM}-5$ catalyst

Compound/Formula
Saturated chain hydrocarbon
Dodecane $/ \mathrm{C}_{12} \mathrm{H}_{26}$
Tridecane $/ \mathrm{C}_{13} \mathrm{H}_{28}$
Tetradecane $/ \mathrm{C}_{14} \mathrm{H}_{30}$
Pentadecane $/ \mathrm{C}_{15} \mathrm{H}_{32}$
Hexadecane $/ \mathrm{C}_{16} \mathrm{H}_{34}$
Heptadecane/ $\mathrm{C}_{17} \mathrm{H}_{34}$
Octadecane $/ \mathrm{C}_{18} \mathrm{H}_{38}$
Nonadecane $/ \mathrm{C}_{19} \mathrm{H}_{40}$
Eicosane $/ \mathrm{C}_{20} \mathrm{H}_{42}$
Heneicosane $/ \mathrm{C}_{21} \mathrm{H}_{44}$
Tetracosane $/ \mathrm{C}_{24} \mathrm{H}_{50}$
Aromatic
2-methylnapthalene/ $\mathrm{C}_{11} \mathrm{H}_{10}$
Methylnaphtalene/ $\mathrm{C}_{11} \mathrm{H}_{10}$

\section{Cycloalkane/Saturated naphthene}

Isobutylcyclopentane $/ \mathrm{C}_{9} \mathrm{H}_{18}$

0.43<smiles>CC(C)CC1CCCC1</smiles>

Heptylcyclohexane/ $\mathrm{C}_{13} \mathrm{H}_{26}$

Cyclohexadecane $/ \mathrm{C}_{16} \mathrm{H}_{32}$

Undecylcyclohexane $/ \mathrm{C}_{17} \mathrm{H}_{34}$

2.59<smiles>CCCCCCCCC1CCCCC1</smiles>

1,3-Dimethyl-(3,7-dimethyloctyl) cyclohexane/ 1.62<smiles>CCCCCCCCCCCCC1CCCCC1</smiles>

$\mathrm{C}_{18} \mathrm{H}_{36}$<smiles>CC(C)CCC[C@@H](C)CCC1C(C)CCCC1C</smiles> 
Continued...(Table 3)

1-(1,5-Dimethylhexyl)-4-(4-methylpentyl) cyclohexane $/ \mathrm{C}_{20} \mathrm{H}_{40}$

0.44

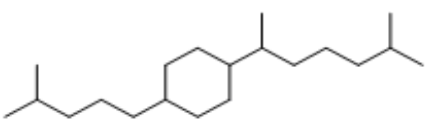

\section{Olefin/Alkenes}

8-Heptadecene

3-Heptadecene/ $\mathrm{C}_{17} \mathrm{H}_{34}$

1-Heptadecene

5.88

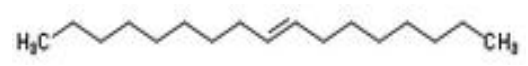

Carboxylic acid

Octanoic Acid

Nonanoic acid

Octadecyl acetate

Oleic acid

Palmitic acid

2.86
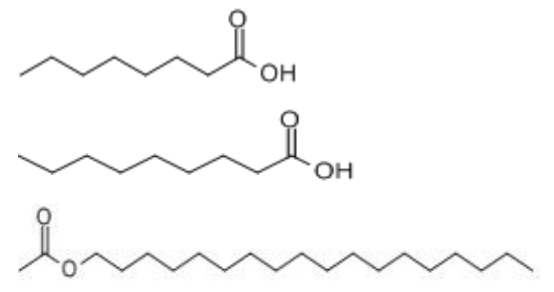

Compounds containing oxygen

6,10,14-Trimethyl-2-pentadecanone

Cyclopentadecanone

cis-9-Hexadecenal

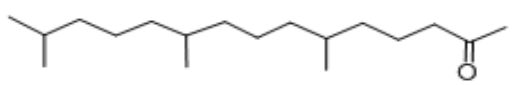

0.97

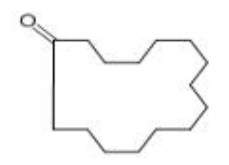

3.04

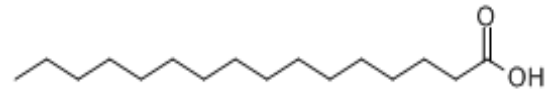

*Adopted from table format in literature [32]

abundant compounds contained in biofuel which can be divided into each type of hydrocarbons at $375^{\circ} \mathrm{C}$ with $\mathrm{Co}-\mathrm{Ni}(10 \% ; 1: 3) / \mathrm{HZSM}-5$ catalyst. The composition of $n$-paraffin formed at this temperature contained the main components of pentadecane of 21.4 area $\%$, hexadecane of 3.1 area\%, heptadecane of 26.79 area\% and octadecane of 2.96 area\%. It was not much different also found in biofuel produced at a temperature of $375{ }^{\circ} \mathrm{C}$ with CoNi(5\%;1:3)/HZSM-5 catalyst. The composition of n-paraffin formed at this temperature contained the main components of pentadecane of 26.79 area\% and heptadecane of 17.38 area\%.

Based on this result, n-C17 and n-C15 were the most abundant hydrocarbon compounds in biofuel. This result is similar to Veriansyah et al. [12]. They found that the first most abundant component was $\mathrm{n}-\mathrm{C} 17$ and the second most abundant component was n-C15. It indicated that decarboxylation and/or decarbonyla- tion was the dominant reaction pathways.

The n-C17 and n-C18 were main contituents in gasoil. In Cerberra manghas oil, fatty acids have carbon atom number of 18 , so that the ratio of $\mathrm{n}-\mathrm{C} 18 / \mathrm{n}-\mathrm{C} 17$ provide useful information about how decarboxilation hydrodeoxygenation reactions take place during process of hydrogenation [31,34]. In this case, the ratio of C18/C17 obtained were very small, then decarboxylation reaction dominates during hydrocracking reaction. Liu et al. [36] stated that the differences in the amount of paraffin obtained for different catalysts was due to the transition metals as active material. They are mainly responsible for the hydrogenation of unsaturated triglyceride and the acidic zeolite contributes to increase the degree of hydrocracking. Therefore, different amount of alkanes in biofuel can be obtained by $\mathrm{Ni}$ supported on zeolites with different acidic strength. 
3.2.2.2. Effect of temperature on gasoline / kerosene / gasoil yields

The analysis results of biofuel were compared with the results of GC-MS commercial fuel sold to the public refueling unit [15]. Beside that, biofuel produced was identified based on a hydrocarbon fractions, which was defined as gasoline-like hydrocarbon (C5-C9), kerosene-like hydrocarbon (C10-C13), and gasoillike hydrocarbon (C14-C22). Figure 10 shows that gasoline/kerosene/gasoil yields for the liquid product produced with Co-Ni/HZSM-5 catalyst at reaction temperature ranging from 300 to $375{ }^{\circ} \mathrm{C}$. Yield of gasoil produced in-

Table 4. Several abundant compounds* in each group for liquid product produced at temperature of $375{ }^{\circ} \mathrm{C}$, under 15 bar in the batch reactor with $\mathrm{Co}-\mathrm{Ni}(10 \% ; 1: 3) / \mathrm{HZSM}-5$ catalyst

Compound/Formula
Saturated chain hydrocarbon
Dodecane $/ \mathrm{C}_{12} \mathrm{H}_{26}$
Tridecane $/ \mathrm{C}_{13} \mathrm{H}_{28}$
Tetradecane $/ \mathrm{C}_{14} \mathrm{H}_{30}$
Pentadecane $/ \mathrm{C}_{15} \mathrm{H}_{32}$
Hexadecane $/ \mathrm{C}_{16} \mathrm{H}_{34}$
Heptadecane $/ \mathrm{C}_{17} \mathrm{H}_{34}$
Octadecane $/ \mathrm{C}_{18} \mathrm{H}_{38}$
Eicosane $/ \mathrm{C}_{20} \mathrm{H}_{42}$
Heneicosane $/ \mathrm{C}_{21} \mathrm{H}_{44}$
Tricosane $/ \mathrm{C}_{23} \mathrm{H}_{48}$

\section{Aromatic}

\section{Cycloalkane/Saturated naphthene}

1,3-Dicyclohexylpropane/ $\mathrm{C}_{15} \mathrm{H}_{28}$

1.26

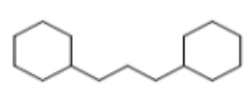

1-(1,5-Dimethylhexyl)-4-(4-methylpentyl)

0.77

cyclohexane $/ \mathrm{C}_{20} \mathrm{H}_{40}$

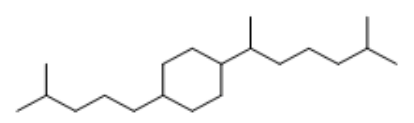

Cyclotetradecane, 1,7,11-trimethyl-4 (1-

methylethyl)-/ $\mathrm{C}_{20} \mathrm{H}_{40}$

0.53

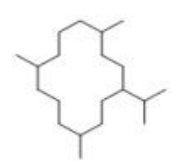

\section{Olefin/Alkenes}

8-Heptadecene

1-Tetradecene/ $\mathrm{C}_{14} \mathrm{H}_{28}$

3-Tetradecene

1-Hexacosene/ $\mathrm{C}_{26} \mathrm{H}_{52}$
12.93

0.69

0.51
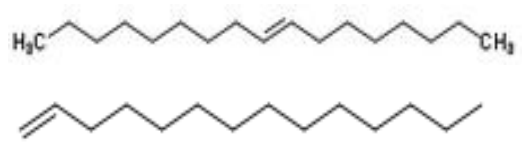

2.77

*Adopted from table format in literature [32] 
creases with increasing temperature as shown in Figure 10 (a), (c), and (d). The increasing reaction temperature causes gasoil increase because of abundant main component, i.e. pentadecane (n-C15) and heptadecane (n-C17). Figure 10(b) shows gasoil reduced from $70.08 \%$ at a temperature of $350{ }^{\circ} \mathrm{C}$ to $66.42 \%$ at a temperature of $375{ }^{\circ} \mathrm{C}$. This decline is probably due to the occurrence of cracking of C18-C23 hydrocarbons into kerosene (C10-C13) [32]. The decarboxylation / decarbonylation reaction occurs at temperatures above $300{ }^{\circ} \mathrm{C}[12,31,32,34,35]$.

In the metal loading of $5 \%$ and $10 \%$ on a metal ratio of $\mathrm{Co}: \mathrm{Ni}=1: 1$, the aromatic compounds in the range 3-6 area\% were found in gasoline and kerosene at a temperature of 375 ${ }^{\circ} \mathrm{C}$. Pentil benzene was found in gasoline of 1.97 $\%$, while 2-methylnaphthalene, methylnaphthalene, heptylbenzene, and 2,3dimethylnaphthalene were found in kerosene of $12.37 \%$ as shown in Figure 10(a). Gasoil of $60.94 \%$ still contain a small amount of aromatic compounds, i.e. nonylbenzene of 1.28 area $\%$ and octylbenzene of 0.96 area\%. Within the limits which have been set, the aromatic hydrocarbon could decrease cetane number in gasoil. In contrast, the aromatic hydrocarbon

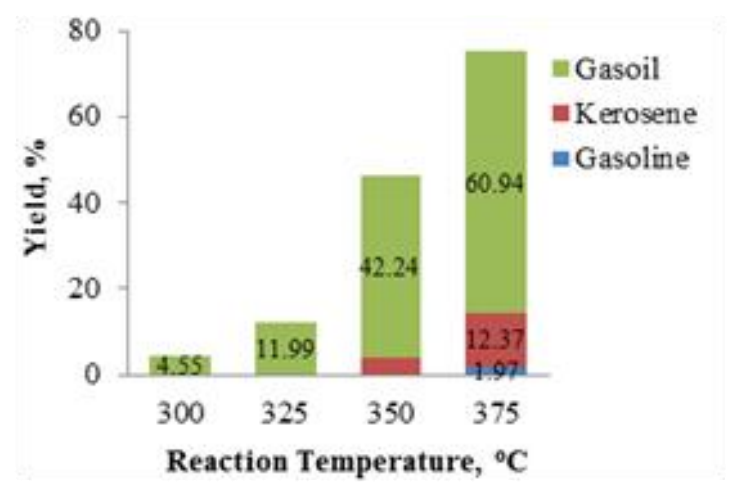

(a)

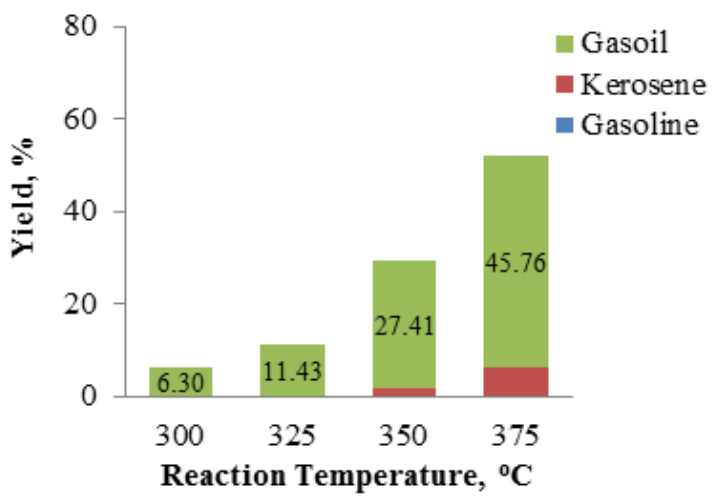

(c) could increase octane number in gasoline. Metals added on HZSM-5 could cause acidity of zeolite to be reduced. As reported by the authors in previous study, Brönsted site on the zeolite as strong acid site can promote isomerization and cyclization reactions. That is why isoparrafin was not found in gasoil. Gasoil whose main components of isoparaffin had a low pour point which indicates the quality of gasoil product $[2,12,34,36]$.

In the metal loading of $5 \%$ and $10 \%$ on a metal ratio of $\mathrm{Co}: \mathrm{Ni}=1: 3$, yield of gasoil obtained reached more than 45 area\% whereas aromatic compound was not be found at a temperature of $350{ }^{\circ} \mathrm{C}$. Gasoil yield of $70.08 \%$ obtained with $\mathrm{Co}-\mathrm{Ni}(5 \% ; 1: 3) / \mathrm{HZSM} 5$ catalyst had abundant main component, namely pentadecane (n-C15) and heptadecane (n-C17) which showed that hydrocracking reaction was dominated by decarboxylation / decarbonylation, as reported by Veriansyah et al. [12]. Meanwhile, gasoil yield of $48.43 \%$ obtained with Co-Ni(10\%;1:3)/HZSM5 catalyst had abundant main component, i.e. tetradecane (n-C14), hexadecane (n-C16), heptadecane (n-C17), and octadecane (n-C18) which showed a balance of reaction occurred between hydrodeoxygenation

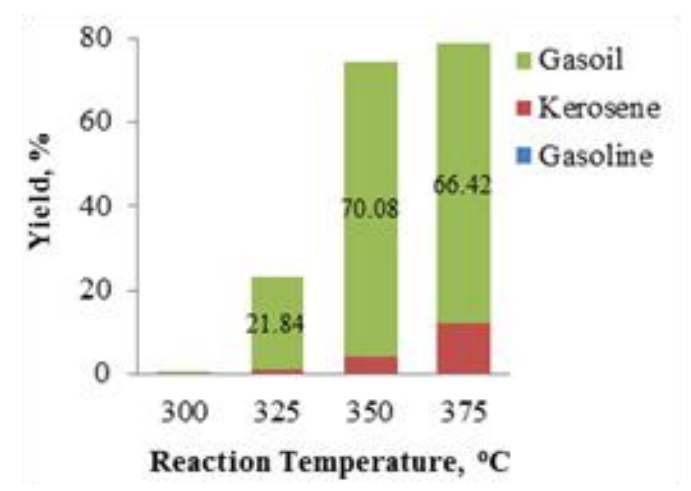

(b)

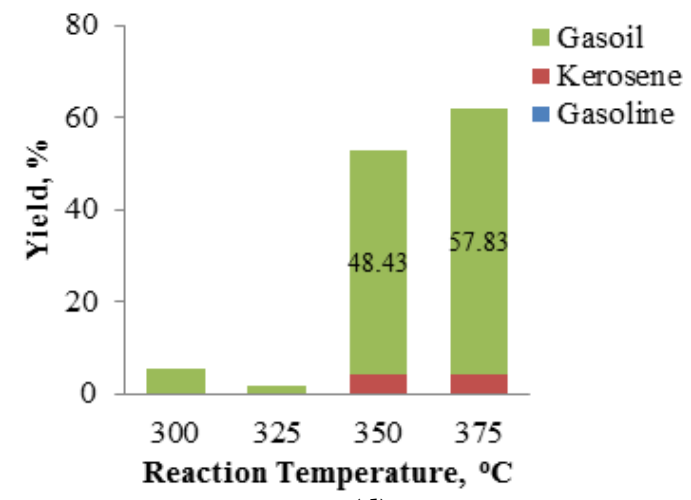

(d)

Figure 10. Effect of reaction temperature on gasoline/kerosene/gasoil yields of liquid product produced using (a) Co-Ni(5\%;1:1)/HZSM-5 catalyst, (b) Co-Ni(5\%;1:3)/HZSM-5 catalyst, (c) Co$\mathrm{Ni}(10 \% ; 1: 1) / H Z S M-5$ catalyst, (d) Co-Ni(10\%;1:3)/HZSM-5 catalyst, under 15 bar in the batch reactor 
and decarboxylation/decarbonylation. However, a temperature of $350{ }^{\circ} \mathrm{C}$, biofuel produced still contained carboxylic acids and olefins in the range $10.87-14.84$ area $\%$ and $17-22.9$ area $\%$, respectively. Both compounds were not completely converted into paraffin compounds. The increasing reaction temperature was favour to conduct further cracking of the carboxylic acids and olefins. Therefore, the cracking reaction was carried out at temperatures above $350{ }^{\circ} \mathrm{C}$, to produce high quality gasoil as fuel. Apparently, at temperature of $375{ }^{\circ} \mathrm{C}$, fatty acids were not found in gasoil produced. Nonylbenzene of 1 area\% in gasoil was found insignificant number. The $\mathrm{n}-\mathrm{C} 15$ and $\mathrm{n}-\mathrm{C} 17$ were still abundant main components found in gasoil of $66.42 \%$ with a $\mathrm{Co}-\mathrm{Ni}(5 \% ; 1: 3) / \mathrm{HZSM}-5$ catalyst and gasoil of $57.83 \%$ with Co$\mathrm{Ni}(10 \% ; 1: 3) / \mathrm{HZSM}-5$ catalyst. Marlinda et al. [38] also reported that $\mathrm{n}-\mathrm{C} 15$ of 20.06 area\% and $\mathrm{n}-\mathrm{C} 17$ of 14.13 area\% were still abundant main components found in gasoil with $\mathrm{Co}(0.88 \%)-\mathrm{Ni}(3.92 \%) / \mathrm{HZSM}-5$ catalyst at temperature of $350{ }^{\circ} \mathrm{C}$.

\section{Conclusions}

The effects of various reaction temperatures on the hydrocracking of Cerbera manghas oil to produce a paraffin-rich mixture of hydrocarbons with $\mathrm{Co}-\mathrm{Ni} / \mathrm{HZSM}-5$ catalyst were studied using a pressure batch reactor system. The composition of biofuel was strongly influenced by reaction temperature, metal loading and metal ratio supported on HZSM- 5 catalyst. At a temperature of $375{ }^{\circ} \mathrm{C}$, n-paraffins content in gasoil-like hydrocarbon were in the range of 57-66 area\% with Co-Ni(5\%:1:3)/HZSM-5 or Co-Ni(10\%:1:3)/HZSM-5 catalyst and in the range of 45-61 area\% with CoNi(5\%:1:1)/HZSM-5 or Co-Ni(10\%:1:1)/HZSM-5 catalyst. It indicated that higher rates of decarboxylation/decarbonylation were influenced by significant $\mathrm{C}-\mathrm{C}$ bond scission in the presence of $\mathrm{Ni}$ catalyst. The first most abundant component is $\mathrm{n}-\mathrm{C} 17$ and the second most abundant component is $\mathrm{n}-\mathrm{C} 15$. It indicated that decarboxylation and/or decarbonylation are the dominant reaction pathways. At this temperature, aromatic compound in gasoline-like hydrocarbon was 6.16 area\% with Co-Ni(5\%:1:1)/HZSM-5 catalyst. The increasing reaction temperature was favour to conduct further cracking of the carboxylic acids and olefins.

\section{Acknowledgement}

The authors would like to acknowledge DRPM, Directorate General of Research and Development, the Ministry of Research, Technology and Higher Education of Indonesia for the research grant supporting this work. The authors are also appreciate to Nunki Fathurrozi and Noveriyanto Dwi Singgih for their contribution during working in chemical reaction engineering laboratory, Department of Chemical Engineering, Sepuluh Nopember Institute of Technology.

\section{References}

[1] Atabani, A.E., Silitonga, A.S., Ong, H.C., Mahlia, T.M.I., Masjuki, H.H., Badruddin, I A., Fayaz, H. (2013). Non-Edible Vegetable Oils: A Critical Evaluation of Oil Extraction, Fatty Acid Compositions, Biodiesel Production, Characteristics, Engine Performance and Emissions Production. Renewable and Sustainable Energy Reviews, 18: 211-245.

[2] Kim, S.K., Brand, S., Lee, H., Kim, Y., Kim, J. (2013). Production of Renewable Diesel by Hydrotreatment of Soybean Oil: Effect of Reaction Parameters. Chemical Engineering Journal, 228: 114-123.

[3] Romero, M., Pizzi, A., Toscano, G., Casazza, A.A., Busca, G., Bosio, B., Arato, E. (2015). Preliminary Experimental Study on Biofuel Production by Deoxygenation of Jatropha Oil. Fuel Processing Technology, 137: 31-37.

[4] Furimsky, E. (2013). Hydroprocessing Challenges in Biofuels Production. Catalysis Today, 217: 13-56.

[5] Yigezu, Z.D., Muthukumar, K. (2014). Catalytic Cracking of Vegetable Oil with Metal Oxides for Biofuel Production. Energy Conversion and Management, 84: 326-333.

[6] Verma, D., Rana, B.S., Kumar, R., Sibi, M.G., Sinha, A.K. (2015). Diesel and Aviation Kerosene with Desired Aromatics from Hydroprocessing of Jatropha Oil over Hydrogenation Catalysts Supported on Hierarchical Mesoporous SAPO-11. Applied Catalysis A: General, 490: 108-116.

[7] Satyarthi, J.K., Srinivas, D. (2011). Fourier Transform Infrared Spectroscopic Method for Monitoring Hydroprocessing of Vegetable Oils to Produce Hydrocarbon-Based Biofuel. Energy Fuels, 25: 3318-3322.

[8] Zhang, H, Lin H., Zheng, Y. (2014). The Role of Cobalt and Nickel in Deoxygenation of Vegetable Oils. Applied Catalysis B: Environmental, 160-161: 415-422. 
[9] Ishihara, A., Fukui, N., Nasu, H., Hashimoto, T. (2014). Hydrocracking of Soybean Oil using Zeolite-Alumina Composite Supported NiMo Catalyst. Fuel, 134: 611-617.

[10] Arun, N., Sharma, R.V., Dalai, A.K. (2015). Green Diesel Synthesis by Hydrodeoxygenation of Bio-Based Feedstocks: Strategies for Catalyst Design and Development. Renewable and Sustainable Energy Reviews, 48: 240-255.

[11] Teixeira da Silva, V., Sousa, L.A. (2013). Catalytic Upgrading of Fats and Vegetable Oils for the Production of Fuels, Chapter 3. The Role of Catalysis for the Sustainable Production of Bio-fuels and Bio-chemicals: Elsevier B.V.

[12] Veriansyah, B., Han, J.Y., Kim, S.K., Hong, S., Kim, Y.J., Lim, J.S., Shu, Y.W., Oh, S., Kim, J. (2012). Production of Renewable Diesel by Hydroprocessing of Soybean Oil: Effect of Catalysts, Fuel, 94: 578-585.

[13] Pinto, F., Varela, F.T., Gonçalves, M., Neto André, R., Costa, P., Mendes, B. (2014). Production of Bio-Hydrocarbons by Hydrotreating of Pomace Oil. Fuel, 116: 84-93.

[14] Roesyadi, A., Danawati, H P., Nurjannah, N., Savitri, S.D. (2013). HZSM-5 Catalyst for Cracking Palm Oil to Gasoline: A Comparative Study With and Without Impregnation. Bulletin of Chemical Reaction Engineering \& Catalysis, 7 (3): 185-190.

[15] Rismawati, R., Prihartantyo, A., Mahfud, M., Roesyadi, A. (2015). Hydrocracking of Calophyllum inophyllum Oil with Non-Sulfide CoMo Catalysts. Bulletin of Chemical Reaction Engineering \& Catalysis, 10(1) : 61-69.

[16] Rismawati, R., Prihartantyo, A., Mahfud, M., Roesyadi, A. (2015). Hydrocracking of Nyamplung Oil (Calophyllum inophyllum Oil) using $\mathrm{CoMo} / \mathrm{Y}^{-} \mathrm{Al}_{2} \mathrm{O}_{3}$ and $\mathrm{CoMo} / \mathrm{SiO}_{2}$ Catalysts. Modern Applied Science, 9: No. 7.

[17] Budianto, A., Danawati, H P., Budhikarjono, K. (2014). Biofuel Production from Candlenut Oil using Catalytic Cracking Process with Zn/HZSM-5 Catalyst. ARPN Journal of Engineering and Applied Sciences, 9: No. 11.

[18] Budianto, A., Danawati, H.P., Roesyadi, A., Budhikarjono, K. (2014). HZSM-5 Catalyst for Cracking Palm Oil to Biodiesel : A Comparative Study With and Without Pt and Pd Impregnation. Scientific Study \& Research Chemistry \& Chemical Engineering, Biotechnology, Food Industry, 15 (1): 081-090.

[19] Shimura, K., Miyazawa, T., Hanaoka, T., Hirata, S. (2015). Fischer-Tropsch Synthesis over Alumina Supported Bimetallic $\mathrm{Co}-\mathrm{Ni}$ Catalyst: Effect of Impregnation Sequence and Solution. Journal of Molecular Catalysis A: Chemical, 407: 15-24.
[20] Stockwell, D.M., Lerner, B.A. (2013). Hydrocracking Catalyst and Process Using Insitu Produced Y-Fauajasite. Patent No. US 8372772 B2, United Stated Patent.

[21] Sartipi, S., Parashar, K., Valero-Romero, M. J., Santos, V.P., Bart van der Linden, Makkee, M., Kapteijn, F., Gascon, J. (2013). Hierarchical H-ZSM-5 Supported Cobalt for Direct Synthesis of Gasoline Range Hydrocarbon from Syngas: Advantages, Limitation, and Mechanistic Insight. Journal of Catalysis, 305: 179-190.

[22] Haber, J., Block, J.H., Delmon, B. (1995). Manual of Methode and Procedures for Catalyst Characterization, Technical Report, Pure \& Appl. Chem., Physical Chemistry Division Commission On Colloid And Surface Chemistry, 67(8/9): 1257-1306.

[23] Hao, K., Shen, B., Wang, Y., Ren, J. (2012). Influence of Combined Alkaline Treatment and Fe-Ti-loading Modification on ZSM-5 Zeolite and Its Catalytic Performance in Light Olefin Production. Journal of Industrial and Engineering Chemistry, 18: 17361740.

[24] Wang, S., Yin, Q.,Guo, J., Ru, B., Zhu, L. (2013). Improved Fischer-Tropsch Synthesis for Gasoline over Ru, Ni Promoted Co/HZSM5 Catalyst. Fuel, 108: 597-603.

[25] Vitale, G., Molero, H., Hernandez, E., Aquino, S., Birss, V., Pereira-Almao, P. (2013). Onepot Preparation and Characterization of Bifunctional Ni-containing ZSM-5 Catalyst. Applied Catalyst A : General, 452: 75-87.

[26] Romero, M.D., Calles, J.A., Rodrı'guez, A., Cabanelas, J.C. (1998), The Influence of Calcination Treatment over Bifunctional Ni/HZSM-5 Catalysts. Industrial and Engineering Chemistry Research, 37: 3846-3852.

[27] Martinez-Grimaldo, H., Ortiz-Moreno, H., Sanchez-Minero, F., Ramirez, J., CuevasGarcia, R., Ancheyta-Juarez, J. (2014). Hydrocracking of Maya Crude Oil in SlurryPhase Reactor. I. Effect of Reaction Temperature. Catalysis Today, 220-222: 295-300.

[28] Barrón, C.A.E., Melo-Bandaa, J.A., Dominguez, E.J.M., Hernández, M.E., Silva, R.R., Reyes, T.A.I., Meraz, M.M.A. (2011). Catalytic Hydrocracking of Vegetable Oil for Agrofuels Production using Ni-Mo, Ni-W, Pt and TFA Catalysts Supported on SBA-15. Catalysis Today, 166: 102-110.

[29] Niu, X., Gao, J., Miao, Q., Dong, M., Wang, G., Fan, W., Qin, Z., Wang, J. (2014). Influence of Preparation Method on the Performance of Zn-containing HZSM-5 Catalysts in Methanol-to-Aromatics. Microporous and Mesoporous Materials, 197: 252-261. 
[30] Gayubo, A.G., Alonso, A., Valle, B., Aguayo, A.T., Olazar, M., Bilbao, J. (2010). Hydrothermal Stability of HZSM-5 Catalysts Modified with Ni for the Transformation of Bioethanol into Hydrocarbons. Fuel, 89: 3365-3372.

[31] Pinto, F., Martins, M., Gonçalves, M., Costa, P., Gulyurtlu, I., Alves, A., Mendes, B. (2013) Hydrogenation of Rapeseed Oil for Production of Liquid Bio-Chemicals. Applied Energy, 102: 272-282

[32] Zheng, X., Chang, J., Fu, Y. (2015). One-pot Catalytic Hydrocracking of Diesel Distillate and Residual Oil Fractions Obtained from Bio-Oil to Gasoline-Range Hydrocarbon Fuel. Fuel, 157: 107-114.

[33] Rabaev, M., Landau, M.V., Vidruk-Nehemya, R., Koukouliev, V., Zarchin, R., Herskowitz, M. (2015). Conversion of Vegetable Oils on $\mathrm{Pt} / \mathrm{Al}_{2} \mathrm{O}_{3} / \mathrm{SAPO}-11$ to Diesel and Jet Fuels Containing Aromatics. Fuel, 161: 287-294.

[34] Sotelo-Boyás, R., Liu, Y., Minowa, T. (2011). Renewable Diesel Production from the Hydrotreating of Rapeseed Oil with Pt/Zeolite and $\mathrm{NiMo} / \mathrm{Al}_{2} \mathrm{O}_{3}$ Catalysts. Industrial and Engineering Chemistry Research, 50 (5): 27912799.
[35] Vichaphund, S., Aht-ong, D., Sricharoenchaikul, V., Atong, D. (2015). Production of Aromatic Compounds from Catalytic Fast Pyrolysis of Jatropha Residues using Metal/HZSM-5 Prepared by Ion-Exchange and Impregnation Methods. Renewable Energy, 79: 28-37

[36] Liu, S., Zhu, Q., Guan, Q., He, L., Li, W. (2015). Bio-aviation Fuel Production from Hydroprocessing Castor Oil Promoted by the Nickel-Based Bifunctional Catalysts. Bioresource Technology, 183: 93-100.

[37] Chen, H., Wang, Q., Zhang, X., Wang, L. (2015). Quantitative Conversion of Triglycerides to Hydrocarbons over Hierarchical ZSM-5 Catalyst. Applied Catalysis B: Environmental, 166-167: 327-334.

[38] Marlinda, L., Al-Muttaqii, M., Roesyadi, A., Danawati, H.P. (2016). Production of Biofuel by Hydrocracking of Cerbera Manghas Oil Using Co-Ni/HZSM-5 Catalyst : Effect of Reaction Temperature. J. Pure App. Chem. Res., 5 (3): 189-195. 